\title{
Economic Challenges of Brain Circulation: The Small Country Case
}

\section{Gindra Kasnauskiene, Prof. Dr.}

\author{
Vilnius University, Faculty of Economics, \\ Sauletekio Ave. 9, LT-10222 Vilnius, Lithuania \\ gindra.kasnauskienė@ef.vu.lt \\ Agne Budvytyte \\ Vilnius University, Faculty of Economics, \\ Sauletekio Ave. 9, LT-10222 Vilnius, Lithuania
}

\section{Doi:10.5901/mjss.2013.v4n9p740}

\begin{abstract}
The world is globalized, and barriers for international movement of highly skilled individuals are less noticeable. More and more qualified people tend to migrate with a purpose of studying and/or working abroad. Nowadays the concept of brain drain is used less often and is being replaced by brain circulation as a phenomenon possibly having a positive impact on the sending as well as the receiving countries. The article discusses the brain circulation concept, analyses the causes that induce the highly skilled individuals to migrate and the consequences to a donor country. The article consists of two main parts. In the first part of the article, an overview of the literature on brain circulation is given; the possible variables that may induce the decision to migrate and what could be done in order to benefit from the migration of the skilled people are discussed. The second part of the article analyses the factors which could prompt a person to move; the impact of the migration of the skilled individuals to a sending country is also discussed. The econometrical analysis of the reasons to move and the consequences on such migration is based on the example of Lithuania.
\end{abstract}

Keywords: brain circulation, skilled migration, consequences, benefits.

\section{Introduction}

International economic forces are pushing countries toward more openness; demographics and technological changes are expanding the demand for skilled workers in growing sectors (Karoly and Panis, 2009). Emigration of highly skilled individuals is often considered as a threat for a country as usually highly qualified people tend to migrate from a developing country to the one that is more developed and richer. That is why international migration of skilled individuals is so often discussed on various occasions.

According to the traditional approach brain drain has a negative impact on the economy. A country loses human capital, as well as the resources that were invested in educating and training the skilled migrants. Furthermore, not all individuals who leave their home country are working in a position that requires their level of education and competence. In such case an individual loses his qualifications and even if one would return to the home country, he would not have the necessary competences to start working immediately. At the same time, if a country faces not only emigration but also has an ageing society this might cause problems in the social security system as well.

However, international movement of highly skilled ones might not always have negative outcomes. The concept of brain circulation is now used more often and does not have a negative meaning like brain drain does. Brain circulation can be used to describe international mobility of highly qualified individuals between their home, destination and other countries. Put it in a different way, it is a global mobility of skilled and competent individuals. In some cases the term brain circulation also refers to the movement of skilled individuals from their home country to receiving country and then back to their home country or, in other words, return migration. As mentioned before, the concept of brain circulation does not have such a negative tinge as brain drain does. On the contrary, brain circulation suggests that international mobility of highly qualified individuals can be beneficial for both home and receiving countries. If a person decides to return back home, he or she usually comes back with a greater experience and brings new ideas. Moreover, in most of cases a person establishes a network abroad. In some cases such networks can stimulate international cooperation between two or more countries. At the same time, even if a person decides not to return to the home country but rather to 
move between few countries or stay in the receiving country, he or she usually maintains a relationship with close relatives or friends in the home country and might want to contribute to the creation of welfare in the home country by providing one's expertise and knowledge or in other means. So basically brain circulation is a positive phenomenon which might help use human resources in a most efficient way.

The purpose of this article is to evaluate what causes brain circulation and what impact the brain circulation has on a countries economy. In order to achieve the main goal econometric analysis based on an example of Lithuania was used.

The article consists of two main parts. In the first part an overview of literature on brain circulation phenomenon is provided. The second part analyses the factors that might induce a person to move. The impact of brain circulation on a countries economy is also evaluated. Finally, a conclusion summarizing the results of the research conducted is provided.

\section{Theoretical framework}

\subsection{The concept of brain circulation}

The brain circulation phenomenon can be defined in different ways. On one hand brain circulation is the movement of a highly qualified individual from home country to another one to work or study and the subsequent return in order to take advantage of the possible career opportunities back in the home country (Bagdanavičius and Juodkiene, 2008; Hall, 2005). Another approach to brain circulation suggests that circulation is moving abroad in seeking better living conditions and later return to the home country to establish new business, retaining business and professional relationships with the destination country (Saxenian, 2005). On the other hand, it is sometimes argued that these definitions of brain circulation refer to return migration which is not the same as brain circulation (Harvey, 2012). Instead it is suggested that brain circulation should be described as a free movement of skilled individuals between home country, destination and other countries (Harvey, 2012). Thus basically an individual does not have to return to the home country in order to contribute to the creation of wealth in one's home country (Meyer and Brown, 1999; Larner, 2007).

\subsection{Brain circulation: preconditions and outcomes}

There are a lot of reasons why highly qualified individuals decide to move from one country to another. If a country is less developed than another one, this could be an incentive for an individual to migrate (Lien and Wang, 2005). If the country has a poor level of development the government cannot assure proper level of education and health security, the economy itself cannot offer career opportunities, technical base for research or competitive salary. These push factors are of course applied to all migrants not necessarily to highly qualified. But if a skilled individual cannot satisfy his basic needs one will make a decision to move to a more developed country with a higher level of income. Also, independently of the level of development of a country, an individual might decide to leave his home country attracted by a higher level of salaries in another country or a possibility to earn more from one's investments in another country (Hall, 2005). Basically better economic situation and higher quality of living conditions might encourage an individual to leave the home country (Harvey, 2011).

Another aspect is non-economic motives to emigrate. Speaking of the movement of highly qualified individuals, these kinds of motives usually have a greater impact on the decision whether to move or not. For example, a chance to enhance the level of qualification and education as well as practice in a specialized field might stimulate one to move to another country which can offer such opportunity (Lee and Kim, 2010). Also, for skilled individuals it is very important to have an interesting and challenging job as well as proper working conditions (Kazlauskienè and Rinkevicius, 2006; Hall, 2005; Harvey, 2011). Weak education system in a country can be as a motive to leave home country as well (Docquier et al., 2007). In some cases, more developed and richer countries try to attract highly qualified individuals by offering them exceptional working and living conditions (Teferra, 2005; Docquier et al., 2007). All these aspects may encourage an individual to move.

Eventually, an individual may decide to come back home. Various motives can prompt one to do that. For example, that the individual cannot adjust to living elsewhere can serve as a motive to come back (Hall, 2005). Even though an individual feels comfortable working abroad he might not feel so when his personal life is considered. Usually, people who find their family, friends and personal life more important than career opportunities or better living conditions tend to consider an option of returning more often because they find it hard to adapt in a new society (Harvey, 2012). 
Also, the economic situation in a home country can change dramatically and there will be no more necessity to stay abroad (Giordano, 2012). Another aspect is that an individual might feel gratitude to their home country and be interested in helping the sending country (Harvey, 2012). In this case one can contribute to the creation of welfare in his home country not necessarily by returning home. This can be done by sharing one's knowledge and information or creating international networks to stimulate the exchange of ideas, experience and resources (Harvey, 2008; Meyer and Brown, 1999).

Speaking of the consequences of the international movement of skilled individuals it is hard to come to one conclusion. If there is only one way movement, a sending country faces problems caused by declining number of population and ageing society (Berzins and Zvidrins, 2011). Also, if a country loses a part of highly qualified population, this might slow the economic and technological development of a country (Docquier et al., 2007) not to mention the fact that the money invested in the education of those individuals is kind of lost since they use their potential and abilities to contribute to the growth of the receiving country (Chaichian, 2012; Verkhohlyad and McLean, 2011).

On the other hand, emigration can reduce unemployment and increase the average salary in a country (Lien and Wang, 2005; Kasnauskienė and Šiaudvytis, 2010). Also, skilled migrants usually earn more and remittances to the home country can increase disposable income and in that way contribute to the growth of consumption as well as savings and investment in the country (Giordano and Terranova, 2012; Kasnauskienè and Buzytè, 2011).

However, the most important benefit of brain circulation is exchange of ideas and experience in an international level. Being a part of an international network of professionals, skilled migrants can help to open their home country's market to the bigger market of the receiving country and encourage the cooperation between the two countries (Saxenian, 2002). Also, by returning to the home country highly qualified individuals can apply their knowledge and experience acquired abroad to mobilize the resources and information in the home country so that they could be used in the most efficient way (Saxenian, 2005; Lee and Kim, 2010). In addition to this, skilled migrants can also assist policy makers back in their home country in creating strategies how to make the most of international migration of highly qualified individuals (Cervantes, 2002).

To conclude, the brain circulation is a phenomenon having a positive impact on both sending and receiving countries. The brain circulation enables to use knowledge, experience and ideas in the most effective way on an international level. Also, it helps to apply the best practices in the less developed countries and stimulate economic as well as technological development.

\section{Modelling causes and consequences of brain circulation}

\subsection{Assumptions}

It is very hard to evaluate the number of highly qualified migrants. There are no sufficient data on migration of the skilled ones in Lithuania. Therefore the data were estimated based on the undeclared emigration of individuals with tertiary education between 2003 and 2007 provided by the Lithuanian department of Statistics. Roughly about one fifth of all the emigrants are individuals with tertiary education. The estimated results on the number of skilled emigration are shown in Figure.

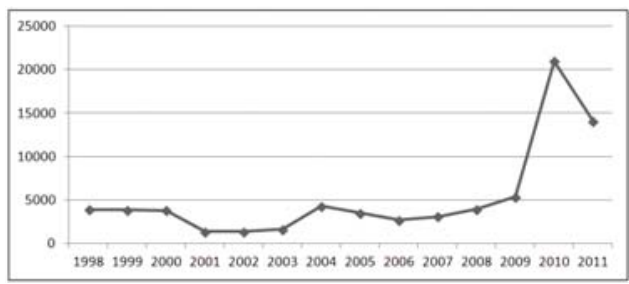

Figure. Estimated number of highly qualified emigrants, Lithuania, 1998-2011

Source: Authors' calculations based on the data provided by Statistics Lithuania.

The 2010 figure was five times higher than the corresponding figures for 2004 and 2005. This increase may, however, include many previous emigrants who only now reported their departures, as deregistration from the population register became mandatory, to avoid compulsory health insurance payments. Having only limited data on the migration of highly 
qualified it was assumed that the brain circulation is a free movement of individuals with tertiary education. When leaving the home country they can move freely between destination, home and third countries not necessarily returning home permanently.

\subsection{Econometric models}

Three models were estimated to evaluate how push and pull factors affect brain circulation as well as how the circulation itself can influence the main economic indicators of a small country. In the first model as push factors unemployment rate of individuals with tertiary education and average net monthly salary were chosen (Hall, 2005; Kazlauskienè and Rinkevičius, 2006). At first, all of these variables were combined into vector error correction model (VECM) which showed that these variables are cointegrated. Yet, autoregressive distribution lags (ADL) model represents the variables better since almost all variables are exogenous. That is why ADL model for brain circulation is a better representation for the variables than VECM. The equation for $\mathrm{ADL}$ is presented below:

\section{$\Delta b c=-34380-1.487 b c_{t-1}+23.76 w_{t-1}+2668 u_{t-1}+17.44 \Delta w-240.4 \Delta u+e_{t}(p$ value 0.06831$)$}

where $\Delta b c$ - difference of brain circulation, $b c_{t-1}$ - lag of brain circulation, $w_{t-1}-$ lag of average net monthly salary, $u t-1$ - lag of unemployment rate of individuals with tertiary education, $\Delta w$ - average net monthly salary difference, $\Delta u-$ difference of unemployment rate of individuals with tertiary education.

The second model was created to evaluate how average net monthly earnings affect brain circulation. Average net monthly earnings in the 15 European Union countries, United Kingdom and United States were chosen since these are the usual destination countries for skilled migrants from Lithuania (Kazlauskienè and Rinkevičius, 2006). Three ADL models were estimated and the equations are presented below:

$\Delta b c=-15940-0.506 b c_{t-1}+9.997$ es $15_{t-1}+18.56 \Delta$ eu15 + et ( $p$ value 0.4137$)$

$\Delta b c=5750.6945-0.3629 b c_{t-1}-1.3323 u k_{t-1}-0.1794 \Delta u k+$ et ( $p$ value 0.7006$)$

$\Delta b c=5633.8306-0.3747 b c_{t-1}-1.5614 u s_{t-1}+6.8152 \Delta u s+$ et ( $p$ value 0.5819$)$

where $\Delta b c$ - difference of brain circulation, $b c_{t-1}$ - lag of brain circulation, eu15t-1 - average net monthly earnings in $15 \mathrm{EU}$ countries, ukt-1 - average net monthly earnings in UK, USt-1 - average net monthly earnings in USA.

The third model was developed in order to evaluate the impact of the brain circulation to some indicators of Lithuania's economy. Gross domestic product per capita in purchasing power parity, average net monthly salary and unemployment rate were chosen since these variables are usually affected by migration (Lien and Wang, 2005; Kasnauskienè and Šiaudvytis, 2010; Karpavičius, 2006). When people leave their home country, in short run, GDP per capita might increase due to the change of population. Since it was estimated that about one fifth of all migrants were highly qualified ones, it is a quite significant change in a country's population. Therefore GDP per capita was included in the model. Average net monthly salary was added to the model since the change in number or population and workforce might affect the average salary. The ones that remain in the country might gain a better negotiation position since eventually a lack in workforce might arise. As for unemployment rate, it is common that emigration and further movement of individuals might decrease the level of unemployed population.

Vector autoregression (VAR) model was evaluated and impulse-response functions as well as forecast error variance decomposition were calculated to assess the impact of brain circulation to the given indicators. The impulseresponse functions show how other variables react to a change of brain circulation. Five periods forward were calculated and explained further. The forecast error variance decomposition indicates what proportion of the variable can be explained by other variables. All the variables were differentiated as they were not stationary. The equations of VAR are given below:

$b c=0.29004-0.04941 e^{e m i t-1}-5.42201 g d p t_{t-1}+2.62315 w_{t-1}-1.76900 U_{t-1}+$ et $(p$ value 0.3788$)$

$g d p=0.14628+0.00215$ emit-1 $-0.19648 g d p_{t-1}-0.78535 w_{t-1}-1.86651 U_{t-1}+$ et $(p$ value 0.2879$)$

$w=0.047685+0.005961 \mathrm{emit}-1+0.108011 \mathrm{gdp} \mathrm{p}_{\mathrm{t}-1}+0.233567 \mathrm{wt}-1^{-1}-1.416551 \mathrm{U}_{\mathrm{t}-1}+$ et $(\mathrm{p}$ value 0.1797$)$

$U=-0.010711-0.001895 \mathrm{emi}_{\mathrm{t}-1}-0.149747 \mathrm{gdp} \mathrm{t}_{\mathrm{t}-1}+0.277914 \mathrm{w}_{\mathrm{t}-1}+0.567616 U_{\mathrm{t}-1}+$ et $(\mathrm{p}$ value 0.07594$)$

where $b c$ - brain circulation, $g d p$ - gross domestic product per capita in PPP, $w$ - average net monthly salary, $U-$ unemployment rate.

Structural Vector Autoregression (SVAR) Model was recreated from Standard VAR. Table 1 and Table 2 show estimated contemporaneous impact matrix and long run impact matrix. The contemporaneous impact matrix shows how the variables of the model affect each other in the short term. It was estimated that in the short term, brain circulation increases GDP per capita and average net monthly salary while decreases unemployment rate. 
Table 1. SVAR estimated contemporaneous impact matrix

\begin{tabular}{|c|c|c|c|c|}
\cline { 2 - 5 } \multicolumn{1}{c|}{} & bc & gdp & w & $U$ \\
\hline bc & 0.53579 & 0.193230 & -0.18411 & 0.028506 \\
\hline gdp & 0.02624 & 0.009534 & 0.05458 & 0.030077 \\
\hline w & 0.03370 & -0.034253 & 0.05335 & 0.022826 \\
\hline$U$ & -0.01347 & -0.001341 & -0.01956 & 0.006967 \\
\hline
\end{tabular}

Source: Authors' calculations based on the data provided by Statistics Lithuania

The long run impact matrix shows the effect each variable on other variables in the model. In the table below the results are given. One can see that in the long run, brain circulation decreases GDP per capita. This situation could arise because in the long run brain circulation might cause a decrease in GDP itself as emigration of highly qualified individuals might slow down economic growth. While in the long run, brain circulation also causes growth of average net monthly salary. As for unemployment rate, brain circulation causes a decrease of the level of unemployed population in the long run.

Table 2. SVAR long run impact matrix

\begin{tabular}{|c|c|c|c|c|}
\cline { 2 - 5 } \multicolumn{1}{c|}{} & bc & gdp & W & $U$ \\
\hline bc & 0.6746984 & 0.000000 & 0.0000000 & 0.00000 \\
\hline gdp & -0.0083393 & 0.040257 & 0.0000000 & 0.00000 \\
\hline W & 0.0483212 & -0.003436 & 0.0700324 & 0.00000 \\
\hline$U$ & -0.0001517 & -0.019252 & -0.0002263 & 0.01611 \\
\hline
\end{tabular}

Source: Authors' calculations based on the data provided by Statistics Lithuania

After SVAR was estimated impulse-response functions and evaluate forecast error variance decomposition were calculated. The results of all the models are given in the next paragraph.

\subsection{Results}

In order to evaluate how the unemployment rate of individuals with tertiary education and average net monthly salary affect brain circulation, cointegrated vector coefficients need to be calculated. The coefficient next to unemployment rate is equal 15.98 while the coefficient next to average monthly salary is 1793.99 . These coefficients show how the lag of unemployment rate and average monthly salary affect brain circulation in the present period. The joint imbalance of brain circulation caused by both change in unemployment rate and monthly salary in the previous time period causes the decrease of brain circulation average 1.49 persons in the present time period. Since the error correction coefficient is not equal to zero, it means that the variables are cointegrated and brain circulation respond to the imbalance caused by unemployment rate of individuals with tertiary education and average net monthly salary.

Evaluated ADL models for pull factors showed how average net monthly earnings in EU 15 countries, United Kingdom and United States influence brain circulation in Lithuania. The model based on the data of EU15 showed that the calculated coefficient next to average net monthly earnings in EU15 is equal to 19.75. The correction coefficient against brain circulation is -0.51 . It means that the change in average net earnings in EU 15 countries in the previous time period causes a decrease of brain circulation by 0.51 persons in the present period. As for the UK case, the calculated coefficient next to average net monthly earnings in UK is -3.67 and the correction coefficient against brain circulation is -0.36 . A change of average net monthly earnings in UK in the past period causes a decrease of brain circulation in the present period. The calculated coefficient in the cointegrated vector equation next to average net monthly earnings in US is -4.17 and the correction coefficient against brain circulation is -0.37 . It means that the imbalance caused by the change of average net monthly earnings in US in the previous time period is eliminated by the decrease of brain circulation by 0.37 persons in the present time period. The results show that the changes of average net monthly earnings in European Union 15 countries, United Kingdom and United States affect the brain circulation in Lithuania. 
The SVAR results show the impact of brain circulation to GDP per capita, average net monthly salary and unemployment rate. In Table 3 impulse-response functions coefficients are given. The response coefficients show how the other variables in SVAR respond to increase of brain circulation at the present period at the same time and five periods ahead.

Table 3. Impulse-response functions

\begin{tabular}{|c|c|c|c|}
\cline { 2 - 4 } \multicolumn{1}{c|}{} & GDP per capita, PPS & $\begin{array}{c}\text { Average net } \\
\text { monthly salary }\end{array}$ & $\begin{array}{c}\text { Unemployment } \\
\text { rate, } \%\end{array}$ \\
\hline$t$ & 0.38424515 & 0.4472702 & -0.54328842 \\
\hline$t+1$ & -0.07814184 & 0.4376362 & -0.12999317 \\
\hline$t+2$ & -0.27759115 & 0.1506715 & 0.33250235 \\
\hline$t+3$ & -0.29738496 & -0.1371184 & 0.42107821 \\
\hline$t+4$ & -0.10450018 & -0.2485036 & 0.23730910 \\
\hline$t+5$ & 0.07695864 & -0.1741849 & -0.03664184 \\
\hline
\end{tabular}

Source: Authors' calculations based on the data provided by Statistics Lithuania

If in the given time period brain circulation increases by one standard deviation - GDP per capita increases by 0.38 standard deviation at the same period. During the next four time periods GDP per capita decreases in response to an increase of brain circulation in the present time period. Only in fifth period GDP per capita starts to increase by 0.08 standard deviations.

The average net monthly salary increases by 0.45 standard deviations at the present period if brain circulation increases by one standard deviation. The increase is also seen during the next two periods. During the last three periods average net monthly salary decreases by $0.14,0.25$ and 0.17 standard deviations respectively.

Unemployment rate decreases by 0.54 standard deviations at the same time period if brain circulation increases by one standard deviation. The decrease is also seen at the first period in the future. During the next periods, up to the fifth one, unemployment rate increases in response to the increase of brain circulation at the present period. From the fifth period unemployment rate starts to decrease by 0.03 standard deviations.

Impulse-response coefficients showed that brain circulation increases GDP per capita at the present time period while during the next four - decreases. The increase in GDP per capita can be explained by the change of population number. While the following decrease in GDP per capita might be caused by the slower rates of economic growth. Since about one fifth of all emigrants are highly skilled, the emigration of qualified individuals might eventually slow the growth of economy. As for average net monthly salary, the first three periods show the growth of net monthly salary caused by brain circulation. Decrease of qualified workforce could impact positively on monthly salary. The results show that during the first two time periods unemployment rate decreases following an increase of brain circulation. While the other three periods show increase in unemployment level.

Table 4 presents the results of forecast error variance decomposition which shows what part of one variable's variance can be explained by itself and other variables.

Table 4. Forecast error variance decomposition

\begin{tabular}{|c|c|c|c|}
\cline { 2 - 4 } \multicolumn{1}{c|}{} & $\begin{array}{c}\text { GDP per capita, } \\
\text { PPS }\end{array}$ & $\begin{array}{c}\text { Average net } \\
\text { monthly salary }\end{array}$ & $\begin{array}{c}\text { Unemployment rate, } \\
\%\end{array}$ \\
\hline $\mathrm{t}+1$ & 0.1476443 & 0.2000507 & 0.2951623 \\
\hline $\mathrm{t}+2$ & 0.1010059 & 0.2525198 & 0.2337118 \\
\hline $\mathrm{t}+3$ & 0.1271269 & 0.2442113 & 0.2045757 \\
\hline $\mathrm{t}+4$ & 0.1520675 & 0.2294293 & 0.2293663 \\
\hline $\mathrm{t}+5$ & 0.1523695 & 0.2351341 & 0.2344839 \\
\hline
\end{tabular}

Source: Authors' calculations based on the data provided by Statistics Lithuania

The forecast error variance decomposition for GDP per capita showed that in the first period forward $14.76 \%$ of the variance of GDP per capita can be explained with brain circulation. The other part of variance can be explained with GDP 
per capita itself and other variables of the model. In the second period forward brain circulation explains $10.10 \%$ of GDP per capita variation. During the third period forward $12.71 \%$ of GDP per capita can be explained with brain circulation. In the fourth and fifth periods forward $15.21 \%$ and $15.24 \%$ on the variance of GDP per capita can be explained with brain circulation. The forecast error variance decomposition for GDP per capita is quite stable that is the same proportion of GDP per capita variance can be explained with brain circulation.

The forecast error variance decomposition for average net monthly salary showed that at the first period forward $20 \%$ of the variance of average net monthly salary can be explained with brain circulation. While during the second and third periods forward $25.25 \%$ and $24.42 \%$ of the variance of average net monthly salary can be explained with brain circulation respectively. At the fourth period forward brain circulation explains $22.94 \%$ of the variance of the average salary and at the fifth $23.51 \%$ of the variance is explained with brain circulation. Again the similar proportion of the variance can be explained with brain circulation during the whole five periods forward.

The forecast error variance decomposition for unemployment rate showed that $29.52 \%$ of the variance of unemployment rate can be explained with brain circulation. During the next three periods in the future brain circulation explains $23.37 \%, 20.45 \%$ and $22.93 \%$ of the variation of unemployment rate. While at the last period brain circulation explains $23.45 \%$ of the variation of unemployment rate. The rest can be explained with other variables of the model. One can see that quite a significant part of the variance of other variables in the model can be explained with brain circulation.

\section{Conclusion}

Brain circulation can be defined as the migration of skilled individuals from their home country to another and then later coming back to their home country to take advantage of new opportunities that have opened up back home. Also, brain circulation can be described as free movement of highly qualified people between their home, destination and other countries with the purpose to work, study or with some other intentions. The factors that shape the scale, nature and circumstances of movement of high qualified people are not fully understood. The immediate and long-term economic impacts of circular migration of skilled individuals for the small sending countries are not clear-cut either.

The analysis provided in this paper has shown that an increase in unemployment rate of individuals with tertiary education together with average net monthly salary decrease brain circulation in Lithuania. Based on this result it could be assumed that the decrease of the two given variables can cause the increase of brain circulation. The analysis of the data of the most common destination countries show that the changes of average net monthly earnings in European Union 15 countries, United Kingdom and United States affect the brain circulation in Lithuania.

The impulse-response functions calculated show that brain circulation has an impact on the GDP per capita, average net monthly salary and unemployment rate variables. The increase of brain circulation reduces GDP per capita while an increase of net monthly salary can be seen during the first few time periods. Unemployment rate decreases at first as a response to the increase of brain circulation.

The forecast error variance decomposition showed that between 12 to $15 \%$ of the variance of GDP per capita can be explained with brain circulation. About $24 \%$ of the variance of average net monthly salary can be explained with brain circulation. Brain circulation explains one fourth of the variance of unemployment rate.

There are no ready-made solutions for effective migration policy. Unfortunately the governance of migration is still relatively underdeveloped. As brain circulation becomes more complex, and it becomes all the more urgent to forge national policy responses that address migration of highly qualified people. Further research is necessary to evaluate the causal links through which brain circulation affects many social and economic indicators in a small country with the high emigration rate.

\section{References}

Bagdanavičius J., Juodkienė Z. (2008). Brain Drain from Lithuania: the Attitude of Civil Servants. Engineering Economics. No 2 (57), p. $55-60$.

Berzins A., Zvidrins P. (2011). Depopulation in the Baltic States. Lietuvos statistikos darbai. No 50, p. 39 - 48.

Cervantes, M.(2002). The Brain Drain: Old Myths, New Realities. OECD http://www.oecdobserver.org/news/archivestory.php/aid/ 673/The_brain_drain:_Old_myths,_new_realities.html

Chaichian M.A. (2012). The new phase of globalization and brain drain. Migration of educated and skilled Iranians to the United States. International Journal of Social Economics. Vol. 39 No 1/2, p. 18-38.

Docquier F., Lohest O., Marfouk A. (2007). Brain Drain in Developing Countries. The World Bank Economic Review. Vol. 21, p. 193 218. 
Eurostat (2013). GDP per capita in purchasing power standards.http://appsso.eurostat.ec.europa.eu/nui/setupModifyTableLayout.do

Eurostat (2013). Unemployment rate of individuals with tertiary education. http://appsso.eurostat.ec.europa.eu/nui/ setupModifyTableLayout.do

Giordano, A., Terranova, G. (2012). The Indian Policy of Skilled Migration: Brain Return Versus Diaspora Benefits. Journal of Global Policy and Governance. Vol. 1, Issue 1, p. 17-28.

Hall P. (2005). Brain drains and brain gains: causes, consequences, policy. International Journal of Social Economics. Vol. 32, p. 939 950.

Harvey W.S. (2012). Brain circulation to the UK?: Knowledge and investment flows from highly skilled British expatriates in Vancouver. Journal of Management Development. Vol. 31, Issue 2, p. $173-186$.

Harvey, W. S. (2011). Immigration and emigration decisions among highly skilled British expatriates in Vancouver. In Taylor et al. (Eds.) Global Knowledge Workers: Diversity and Relational, Edward Elgar, Cheltenham, UK.

Karoly, L.A., Panis, C.W.A. (2009). Supply of and demand for skilled labor in the United States. In J. Bhagwati and G. Hanson (eds) Skilled Immigration Today: Prospects, Problems and Policies. Oxford, UK: Oxford University Press, p. 15-52.

Karpavičius S. (2006). Emigracijos poveikis Lietuvos ekonomikai. Pinigu studijos. No 2, p. 21 - 41.

Kasnauskienė G., Buzytẻ L. (2011). Emigrantu piniginiai pervedimai ir ju poveikis ekonomikai. Pinigu studijos. № 1, p. 31 - 47.

Kasnauskienè G., Šiaudvytis T. (2010). Gyventoju emigracijos poveikio darbo rinkai vertinimas. Lietuvos statistikos darbai. No 49, p. 12 $-19$.

Kazlauskienė A., Rinkevičius L. (2006). Lithuanian "Brain Drain" Causes: Push and Pull Factors. Engineering Economics. No 1, p. 27 37.

Larner, W. (2007). Expatriate experts and globalizing governmentalities: the New Zealand diaspora strategy. Transactions of the Institute of British Geographers. Vol. 32, Issue 3, p. 331-345.

Lee, J.J., Kim, D. (2010). Brain gain or brain circulation? U.S. doctoral recipients returning to South Korea. Higher Education. Vol. 59, Issue 5, p. 627-643.

Lien D., Wang Y. (2005). Brain drain or brain gain: A revisit. Journal of Population Economics. No 18, p. $153-163$.

Meyer J-B., Brown M. (1999). Scientific diasporas: A new approach to the brain drain. Paris: UNESCO-MOST Discussion Paper No. 41. www.unesco.org/most/meyer.htm

Saxenian, A. (2002). Brain circulation: How high-skill immigration makes everyone better off. The Brookings Review (20), 1, p. 28-31.

Saxenian, A. (2005). From brain drain to brain circulation: transnational communities and regional upgrading in India and China. Studies in Comparative International Development 20 (2), p. 35-61.

Statistics Lithuania (2013). Emigration. http://osp.stat.gov.It/statistiniu-rodikliu-analize?id=1296\&status=A

Statistics Lithuania. (2013). Unemployment. http://db1.stat.gov.It/statbank/default.asp?w=1280

Teferra D. (2005). Brain Circulation: Unparalleled Opportunities, Underlying Challenges, and Outmoded Presumptions Damtew. Journal of Studies in International Education. Vol. 9 No 3, Fall, p. $229-250$.

Verkhohlyad O., McLean G. N. (2012). Applying organizational commitment and human capital theories to emigration research. European Journal of Training and Development. Vol. 36, Issue 2, p. 308 - 328. 